\title{
Expression of Striatal Preprotachykinin mRNA in Symptomatic and Asymptomatic 1-Methyl-4-Phenyl-1,2,3,6-Tetrahydropyridine- Exposed Monkeys Is Related to Parkinsonian Motor Signs
}

\author{
Timothy V. Wade and Jay S. Schneider \\ Department of Pathology, Anatomy, and Cell Biology, Thomas Jefferson University, Philadelphia, Pennsylvania 19107
}

Striatal preprotachykinin (PPT) gene expression and $\left[{ }^{3} \mathrm{H}\right]$ mazindol binding were examined in monkeys exposed to 1-methyl4-phenyl-1,2,3,6-tetrahydropyridine (MPTP). Some animals $(n=5)$ became moderately to severely parkinsonian after receiving large doses of MPTP over 9-30 d and remained symptomatic for a relatively short time (3 weeks to 3 months; acutely symptomatic group). A second group of animals $(n=5)$ received low doses of MPTP (1.5-12 months), developed cognitive impairments but displayed no gross motor deficits (asymptomatic group), and were killed 3-12 months after their final dose of MPTP. Other animals became moderately to severely parkinsonian after receiving escalating doses of MPTP $(>6$ months; $n=4)$ or high doses of MPTP ( $<1$ month; $n=1)$ and remained symptomatic for $2.5-5.75$ years (chronically symptomatic group). All MPTP-treated animals had extensive losses of $\left[{ }^{3} \mathrm{H}\right]$ mazindol binding in dorsal striatal sensorimotor regions with asymptomatic animals generally having a lesser degree of

Two distinct subpopulations of GABAergic neurons in the striatum can be distinguished on the basis of their peptide content. Substance P (SP) is coexpressed by GABAergic medium spiny neurons, the efferents of which primarily innervate the internal segment of the globus pallidus and the substantia nigra par reticulata as part of a "direct" striatal output circuit. In contrast, enkephalin is coexpressed by GABAergic neurons, the efferents of which primarily innervate the external segment of the globus pallidus as part of an "indirect" striatal output circuit (Parent and Hazrati, 1995). A normal dopaminergic (DAergic) innervation of the striatum appears to be critical to the proper functioning of these two output pathways. Balanced activities in these circuits are thought to underlie normal motor function (Gerfen, 1992). Disruption of a "balanced opposition" in the activity of these circuits [caused by severe striatal dopamine (DA) denervation] is thought to result in hypoactivity of the direct circuit and hyperactivity of the indirect circuit. This functional alteration in striatal output circuits may underlie many of the motor deficits associated with Parkinson's disease (PD) (Delong, 1990).

In the striatum, expression of mRNA for preprotachykinin (PPT), the precursor polypeptide to SP, decreases in response to nigrostriatal DAergic lesions. Rats lesioned with 6-hydroxydopa-

Received Feb. 22, 2001; revised April 4, 2001; accepted April 16, 2001.

This research was supported by United States Public Health Service Grant MH46531 and by the F. M. Kirby Foundation.

Correspondence should be addressed to Dr. Jay S. Schneider, Department of Pathology, Anatomy, and Cell Biology, Thomas Jefferson University, 1020 Locust Street, 521 JAH, Philadelphia, PA 19107. E-mail: jay.schneider@mail.tju.edu. Copyright @ $\odot 2001$ Society for Neuroscience 0270-6474/01/214901-07\$15.00/0 damage. However, PPT mRNA levels differed sharply among treatment groups. Symptomatic animals (acutely and chronically parkinsonian) had significantly decreased PPT mRNA levels in most striatal regions. In asymptomatic animals, PPT mRNA expression was not significantly different from that measured in control animals, despite decreases in $\left[{ }^{3} \mathrm{H}\right]$ mazindol binding in some striatal regions of similar magnitude to those observed in symptomatic animals. These observations suggest that PPT gene expression may be directly related to expression of parkinsonian motor symptomatology regardless of duration of MPTP exposure, duration of the parkinsonism, or extent of dopamine denervation. These results imply that the direct striatal output circuit may have a greater contribution to expression of parkinsonian symptomatology than proposed previously.

Key words: preprotachykinin; striatum; parkinsonism; dopamine; MPTP; monkey mine (Gerfen et al., 1990; Zeng et al., 1995) and monkeys lesioned with 1-methyl-4-phenyl-1,2,3,6-tetrahydropyridine (MPTP) have significant striatal DAergic denervation accompanied by decreases in PPT mRNA levels of 35-65\% (Herrero et al., 1995; Jolkkonen et al., 1995; Morissette et al., 1999). The number of mRNA transcripts encoding for PPT in the striatum appears to be regulated via tonic facilatory effects of DA on striatal PPT/GABAergic neurons, causing PPT expression to be attenuated in the DAdenervated striatum.

However, the animal models from which these data were collected involved induction of DAergic cell loss over a short period of time and short-term survival after the lesion. Previously, we observed that striatal preproenkephalin (PPE) mRNA levels were significantly upregulated in acutely parkinsonian monkeys but unchanged or downregulated in similarly symptomatic monkeys with long-duration parkinsonism (Schneider et al., 1999). This suggested that the DA denervation-induced changes in striatal PPE gene expression in MPTP-induced parkinsonism may not be directly related to the expression of parkinsonian motor signs. Because PPT and PPE mRNA appear to be localized almost entirely in distinct subpopulations of striatal GABAergic output neurons in the monkey (Aubert et al., 2000), the present study examined the extent to which gene expression for the other major striatal neuropeptide PPT may change in relation to the duration of parkinsonism and the degree of motor symptomatology.

\section{MATERIALS AND METHODS}

Animals. A total of 23 adult male macaque monkeys (Macaca fascicularis, M. nemistrina, and M. mulatta) were used in this study. All animals were 
individually housed in the same room with a $12 \mathrm{hr}$ light/dark cycle. This study was conducted in compliance with established federal and institutional guidelines for the care and use of laboratory animals. Throughout the study, all animals were rated for a variety of behaviors using a previously described Parkinson monkey rating scale (Schneider et al., 1998). This behavioral and motor rating scale evaluates 19 items associated with motor function and other behaviors such as defense reaction and eating ability. A score of 0 is normal; the maximum parkinsonian score that can be achieved is 41 . Ratings were taken twice weekly by an observer blind to the regimen of toxin administration.

Eight animals received no treatment and were used as normal controls. Five animals were given intramuscular injections of MPTP (MPTP$\mathrm{HCl}$, dissolved in sterile normal saline; Research Biochemicals, Natick, $\mathrm{MA}$ ) in doses ranging from 0.33 to $0.75 \mathrm{mg} / \mathrm{kg}$ twice weekly over a period of 9-30 d, producing a moderate-to-severe parkinsonism (acutely symptomatic group). These animals were killed 3 weeks to 3 months after the last MPTP injection.

Five animals received intravenous injections of MPTP at low doses of $0.05-0.15 \mathrm{mg} / \mathrm{kg}$ one to three times weekly over several months (range, 1.5-12 months). This MPTP administration protocol produced animals with cognitive impairments but no gross motor deficits (asymptomatic group). Some of these animals were used previously in behavioral pharmacology studies (Schneider et al., 1998) but had not received any drug treatments for at least 6 months before this study. These animals were killed 3-12 months after their last MPTP injection.

Four additional animals initially received MPTP administration (0.05$0.15 \mathrm{mg} / \mathrm{kg}$ ) identical to that of the asymptomatic group but, after being motor asymptomatic for several months and being tested for cognitive deficits, received additional MPTP administration $(0.33-0.50 \mathrm{mg} / \mathrm{kg})$ to produce moderate-to-severe motor deficits (chronically symptomatic group). These animals were killed 2.5-5.75 years after the last dose of MPTP.

One additional monkey received high doses of MPTP $(0.33 \mathrm{mg} / \mathrm{kg}$, i.m.; twice weekly) for $\sim 1$ month to produce a rapid parkinsonism. The administration protocol was similar to that of the acutely symptomatic group; however, this animal was killed 4 years after the last MPTP injection (chronically symptomatic group).

All animals were killed by sodium pentobarbital overdose $(150 \mathrm{mg} / \mathrm{kg}$, i.v.). Each brain was bisected along the midline, and the two hemispheres were immediately frozen by immersion in $-40^{\circ} \mathrm{C}$ isopentane and stored at $-80^{\circ} \mathrm{C}$.

$\left[{ }^{3} \mathrm{H}\right]$ mazindol autoradiography. Striatal DA denervation was assessed by quantitative receptor autoradiography using $\left[{ }^{3} \mathrm{H}\right]$ mazindol binding to presynaptic striatal DA uptake sites, as described previously (Rioux et al., 1997; Schneider et al., 1999). In brief, 20- $\mu$ m-thick sections were thaw mounted onto gelatin-subbed slides, dried on a slide warmer, and stored desiccated at $-80^{\circ} \mathrm{C}$. Slides were removed from the freezer, incubated on ice, and allowed to thaw at room temperature for $1 \mathrm{~min}$. Slides were then preincubated for $5 \mathrm{~min}$ in Tris buffer containing $300 \mathrm{nM}$ desipramine to block norepinephrine sites, incubated for $40 \mathrm{~min}$ at $4^{\circ} \mathrm{C}$ in the same buffer containing $15 \mathrm{~nm}\left[{ }^{3} \mathrm{H}\right]$ mazindol $(23.5 \mathrm{Ci} / \mathrm{mmol}$; DuPont NEN, Boston, MA), rinsed twice for $3 \mathrm{~min}$ in ice-cold Tris buffer, and then rinsed for $10 \mathrm{sec}$ in ice-cold distilled water. Nonspecific binding was measured in adjacent sections by the addition of $30 \mu \mathrm{M}$ benztropine to the incubation buffer. All slides were dried under a stream of cold air and apposed to ${ }^{3} \mathrm{H}$-hyperfilm (Amersham, Arlington Heights, IL) for $21 \mathrm{~d}$ along with calibrated ${ }^{3} \mathrm{H}$-plastic standards (American Radiolabeled Chemicals, St. Louis, MO). Film was developed in Kodak D19 developer (Eastman Kodak, Rochester, NY) and fixed.

Preprotachykinin in situ hybridization. In situ hybridization histochemistry was performed as described previously (Schneider et al., 1999). Twenty-micrometer-thick sections at three distinct levels of the striatum were processed using an ${ }^{35} \mathrm{~S}$-labeled antisense oligonucleotide probe (Biosynthesis, Inc.) complementary to bases 205-252 of the human PPT cDNA sequence (Harmar et al., 1986). Seven picomoles of the oligonucleotide probe were $3^{\prime}$-tail labeled with $\left[{ }^{35} \mathrm{~S}\right]$ deoxyadenosine $5^{\prime}$ - $(\alpha$-thio)triphosphate $\left(>1000 \mathrm{Ci} / \mathrm{mmol}\right.$; Amersham) using a $3^{\prime}$-terminal transferase kit (Roche Products, Hertforshire, UK). The labeled probe was purified at room temperate and precipitated in ethanol overnight at $-70^{\circ} \mathrm{C}$. The resulting pellet was reconstituted in DEPC water the next day. All striatal sections were pretreated in $3 \%$ paraformaldehyde, $2 \times$ SSC, and $0.1 \mathrm{M}$ triethanolamine, $\mathrm{pH} 8.0$, with $0.25 \%$ acetic anhydride before being dehydrated in ascending concentrations of ethanol. Sections were hybridized overnight at $37^{\circ} \mathrm{C}$ in $60 \mu \mathrm{l}$ of hybridization buffer containing $2.0 \times 10^{6}$ counts of ${ }^{35}$ S-labeled PPT probe. Subsequent

stringency washes were performed at $55^{\circ} \mathrm{C}$ in $0.5 \times \mathrm{SSC}$ for $2 \mathrm{hr}$ before sections were dehydrated in ascending concentrations of ethanol and delipidated in histoclear. The slides were then apposed to $\beta$-Max hyperfilm (Eastman Kodak) for 7-10 d, developed in Kodak GBX developer, and fixed. In control experiments, the specific hybridization signal was

A. Rostral Putamen

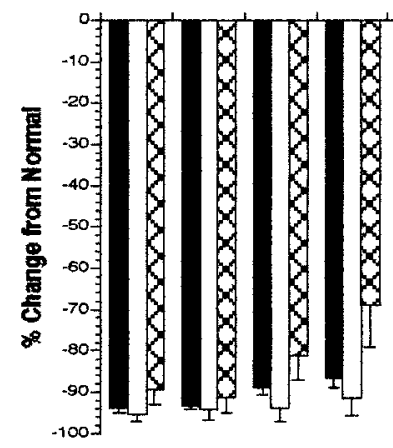

DL DM VL VM

\section{Caudate}

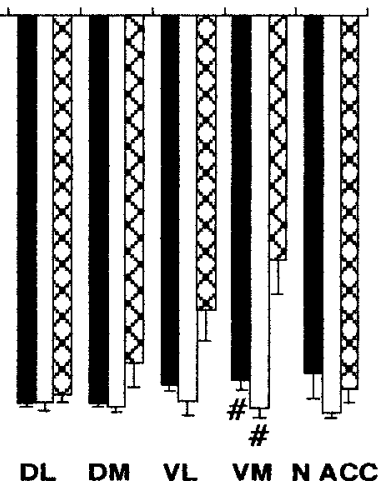

DL. DM VL VM NACC

\section{B. Mid}

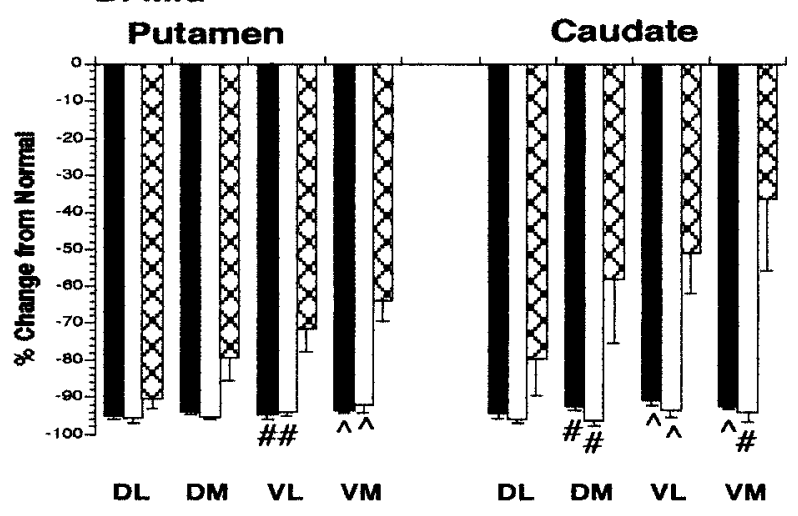

\section{Caudal}

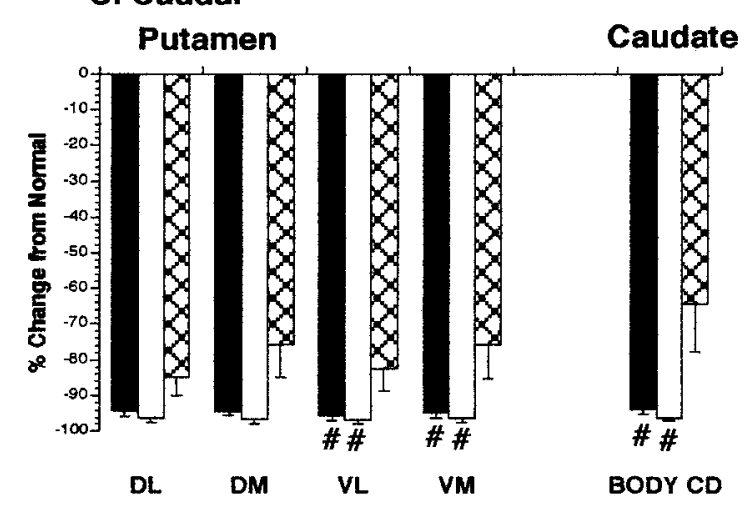

Figure 1. Effect of short-term (acutely symptomatic, black bars), longterm (chronically symptomatic, white bars), and low-dose (asymptomatic, cross-hatched bars) MPTP exposure on presynaptic striatal dopamine uptake sites at three rostrocaudal levels [rostral $(A)$, mid $(B)$, and caudal $(C)]$. Results are expressed as the percentage change from the mean of eight control animals. All MPTP treatment groups at all rostrocaudal levels have highly significant ( $p<0.01$ vs normal controls) losses in specific $\left[{ }^{3} \mathrm{H}\right]$ mazindol binding at all striatal regions. The asymptomatic animals have significantly more $\left[{ }^{3} \mathrm{H}\right]$ mazindol binding than do the symptomatic animals in most ventral regions $\left({ }^{\wedge} p<0.01\right.$ vs asymptomatic group; $\# p<0.05$ vs asymptomatic group). $C D$, Caudate nucleus; $D L$, dorsolateral; $D M$, dorsomedial; $N A C C$, nucleus accumbens; $V L$, ventrolateral; $V M$, ventromedial. 
Normal

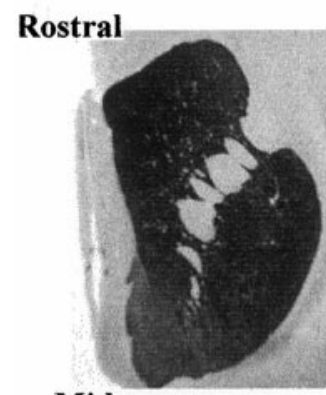

Mid

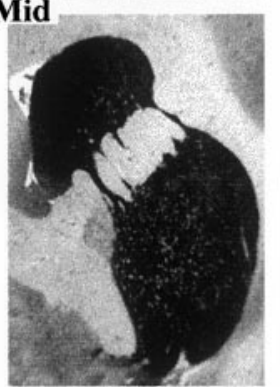

Caudal-

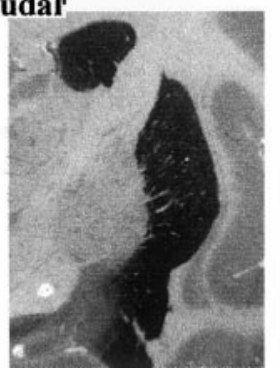

Asymp.
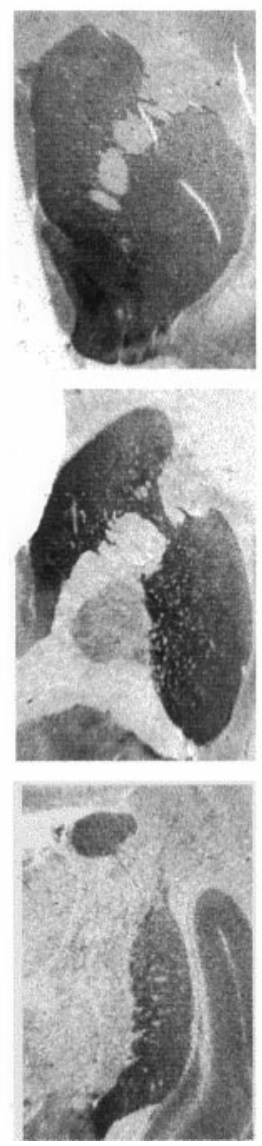

Chronic Symp.
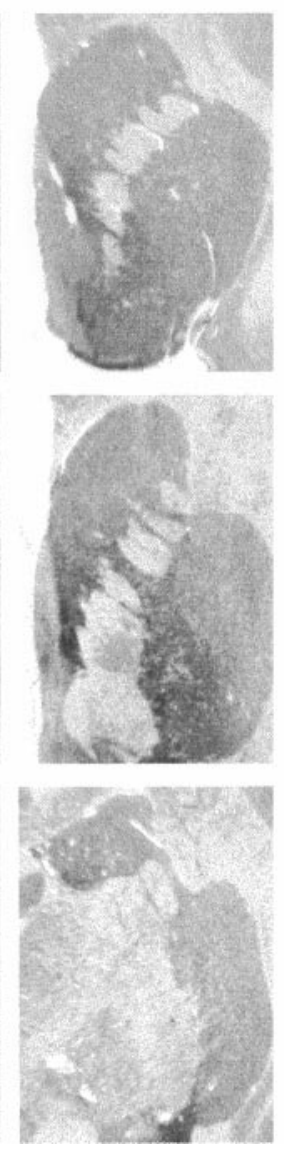

Acute Symp.
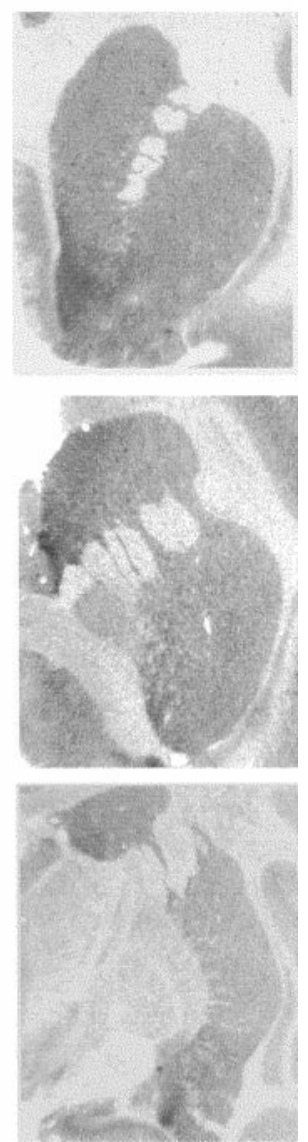

Figure 2. Autoradiograms of total $\left[{ }^{3} \mathrm{H}\right]$ mazindol binding in control (Normal), asymptomatic (Asymp.), acutely symptomatic (Acute Symp.), and chronically symptomatic (Chronic Symp.) monkeys. The top row shows the rostral striatum, including the caudate nucleus, putamen, and nucleus accumbens. The middle row shows the mid level of the striatum, including the caudate nucleus, putamen, and external segment of the globus pallidus. The bottom row shows the caudal striatum, including the putamen, body of the caudate nucleus, and both the internal and external segments of the globus pallidus. Both symptomatic groups show similar losses in total $\left[{ }^{3} \mathrm{H}\right]$ mazindol binding compared with controls, whereas the asymptomatic group shows less extensive losses in medial and ventral regions. eliminated by hybridization with an excess of unlabeled PPT antisense probe or by hybridization with a labeled PPT sense probe.

Data analysis. The striatum was analyzed at three levels: the rostral level (precommissural) including the caudate, putamen, and nucleus accumbens; the mid level including the caudate, putamen, and external globus pallidus at the level of the decussation of the anterior commissure; and the caudal level (postcommissural) including the body of the caudate, the putamen, and both internal and external globus pallidus segments. In each section, the caudate and putamen were subdivided at the rostral and mid levels into dorsal lateral, dorsal medial, ventral lateral, and ventral medial regions. At the caudal level, the putamen was subdivided in the same way, but the body of the caudate was not subdivided (PopeColeman et al., 2000). Levels of PPT mRNA expression were quantified by computerized densitometry using NIH Image software (version 1.58) and standardized by subtracting the specific signal in the striatum from nonspecific signal in an unlabeled area of the section. Three sections per animal per striatal level (rostral, mid, and caudal) were analyzed. A standard gray scale strip (Kodak Photographic Step Tablet No. 3) was used to generate a calibration curve for optical densities, which were averaged for each region in each monkey and expressed as the percentage difference from the mean of control animals. Group differences were assessed by one-way ANOVA followed by post hoc pairwise comparisons with the Student-Newman-Keuls test for multiple comparisons.

$\left[{ }^{3} \mathrm{H}\right]$ mazindol autoradiograms were analyzed using a computer-driven analysis system (BRAIN, version 4.0; Drexel University) at the three rostrocaudal regions described above. At each level, at least three sections were analyzed for total binding, and two sections were analyzed for nonspecific binding. A mean value for each region by level for each case was determined. Group differences were assessed by one-way ANOVA with post hoc pairwise comparisons performed using the Student-Newman-Keuls test for multiple comparisons.

Differences in behavioral ratings between groups were assessed using a Kruskal-Wallis nonparametric ANOVA followed by the Dunn's test for post hoc pairwise comparisons.

\section{RESULTS}

\section{Animals}

Both acutely and chronically symptomatic animals were similarly parkinsonian at the time of death, with behavioral ratings of $34.4 \pm 3.3$ and $33.0 \pm 2.0$, respectively. Asymptomatic animals had no noticeable gross motor deficits (behavioral rating, $1.2 \pm$ 0.2 ) and were not significantly different from normal animals. The monkey with rapid-onset, long-duration parkinsonism had a behavioral rating of 32 and was symptomatically indistinguishable from the other animals in the chronically symptomatic group.

\section{$\left[{ }^{3} \mathrm{H}\right]$ mazindol autoradiography}

Data from some of the normal, acutely symptomatic, and chronically symptomatic animals have been published previously (Schneider et al., 1999). Significant group-by-region effects were observed at all three rostrocaudal levels (rostral level, $F_{(35,203)}=$ 38.42 ; $p<0.0001$; mid level, $F_{(31,191)}=32.59 ; p<0.0001$; caudal level, $\left.F_{(19,120)}=55.83 ; p<0.0001\right)$. Acutely and chronically symptomatic animals had similar degrees of striatal DA denervation in all regions of both the caudate nucleus and the putamen $(p<0.01)$. In comparison, asymptomatic animals had significantly more $\left[{ }^{3} \mathrm{H}\right]$ mazindol binding, particularly in ventral and medial regions of the caudate nucleus and the putamen $(p<0.05$ vs symptomatic animals) (i.e., ventrolateral and ventromedial caudate nucleus and ventromedial putamen), especially at the more caudal levels. In dorsal regions of the caudate nucleus and 
putamen in asymptomatic animals, $\left[{ }^{3} \mathrm{H}\right]$ mazindol binding was similar to that observed in symptomatic animals (Figs. 1, 2).

\section{Preprotachykinin in situ hybridization}

At all rostrocaudal levels, there were significant group-by-region effects on PPT gene expression (rostral level, $F_{(35,160)}=8.02 ; p<$ 0.0001 ; mid level, $F_{(31,144)}=7.68 ; p<0.0001$; caudal level, $F_{(19,95)}$ $=9.41 ; p<0.0001)$. At the rostral level, acutely symptomatic animals had significantly decreased PPT gene expression in all dorsal and ventral regions of the caudate and putamen compared with both normal and asymptomatic animals (Figs. 3, 4). In chronically symptomatic animals, significantly decreased PPT gene expression was observed in most rostral striatal regions with the exception of the ventromedial putamen and the ventrolateral caudate nucleus (Figs. 3, 4). No significant changes in PPT mRNA levels were observed in the nucleus accumbens.

At the mid level, significantly decreased PPT gene expression [compared with that of both normal and asymptomatic animals $(p<0.05)$ ] was found in all striatal regions in acutely symptomatic animals (Figs. 3, 4). In chronically symptomatic animals, significantly decreased PPT gene expression was found in most striatal regions with the exception of the ventromedial putamen (Figs. 3, 4).

At the caudal level, PPT mRNA levels were decreased to a great extent in both acutely and chronically symptomatic animals, with the greatest decreases in gene expression observed in putamen regions. No significant decreases in PPT mRNA expression were observed at any rostrocaudal level in any striatal region in asymptomatic animals.

\section{DISCUSSION}

The results of this study show that downregulation of striatal PPT mRNA levels is associated with expression of motor signs of parkinsonism in monkeys exposed to MPTP. Animals displaying moderate-to-severe parkinsonian motor symptoms had the greatest reductions in PPT mRNA levels, whereas animals that were essentially asymptomatic for a parkinsonian motor disorder had no significant changes in PPT mRNA expression in any striatal region. All symptomatic animals had similar decreases in $\left[{ }^{3} \mathrm{H}\right]$ mazindol binding in dorsal striatal regions. Asymptomatic animals also had large decreases in dorsal striatal $\left[{ }^{3} \mathrm{H}\right]$ mazindol binding particularly in dorsal lateral regions but had significant sparing of $\left[{ }^{3} \mathrm{H}\right]$ mazindol binding in ventral striatal regions. This may suggest a larger contribution of the ventral striatal DAergic innervation to expression of parkinsonian symptoms than thought previously. Although modest decreases in PPT expression were observed in asymptomatic animals at mid and caudal striatal levels, the magnitude of these changes was significantly less than that observed in symptomatic animals.

In agreement with other reports (Morissette et al., 1999), we found that striatal PPT gene expression in normal animals follows a rostrocaudal-mediolateral gradient with somewhat greater levels of PPT mRNA expressed more medially and caudally. We also noted a "patchy" distribution of PPT mRNA in normal and asymptomatic animals (Morissette et al., 1999; Aubert et al., 2000) that was partially preserved in the caudate but absent in the putamen in both acutely and chronically symptomatic animals. Striatal striosomes are known to be enriched in immunoreactivity for substance P (Beach and McGeer, 1984), to receive DAergic projections primarily from the ventral densocellular A9 region (Langer and Graybiel, 1989), and to project preferentially to the substantia nigra pars compacta (Gerfen, 1984). In the primate

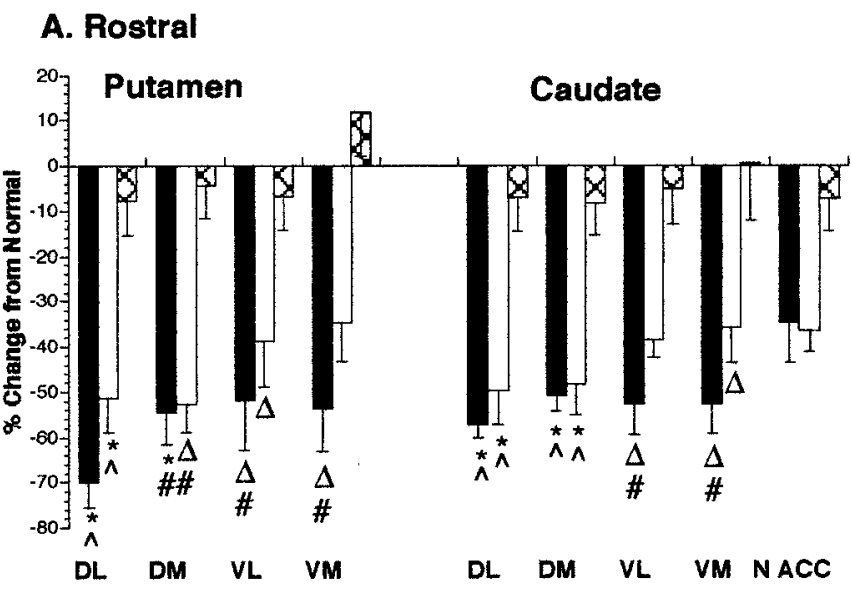

B. Mid

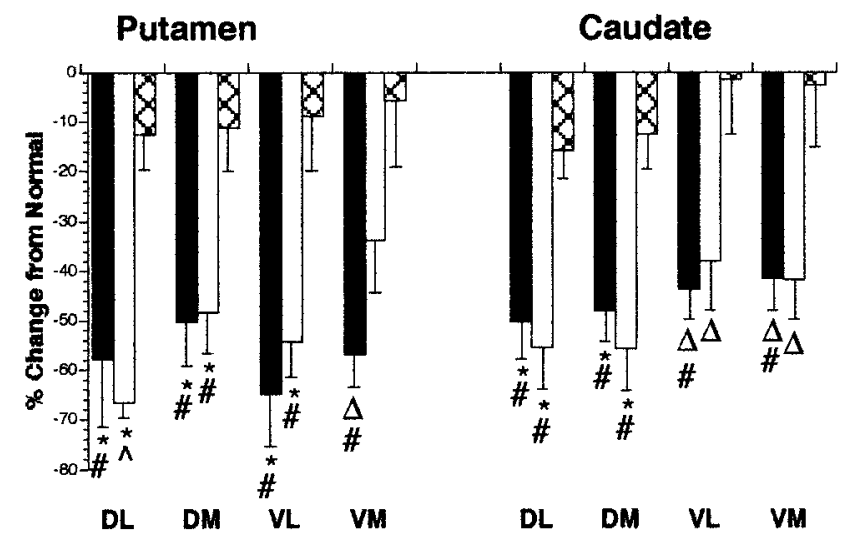

C. Caudal

Putamen

Caudate

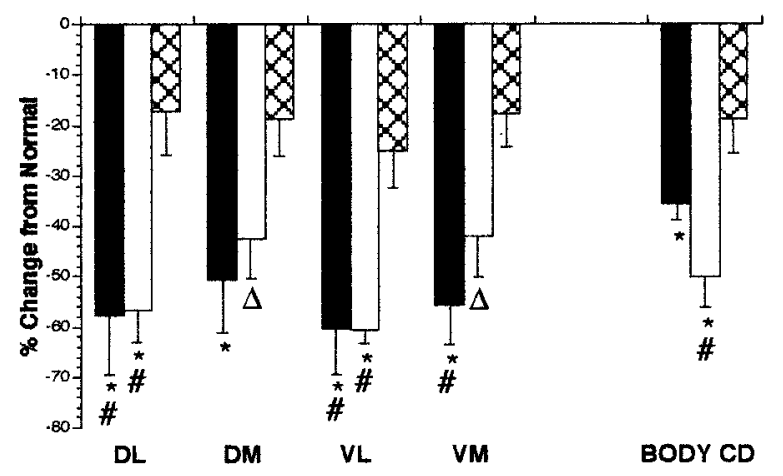

Figure 3. Effect of short-term [acutely symptomatic $(n=5)$, black bars], long-term [chronically symptomatic $(n=5)$, white bars], and low-dose [asymptomatic $(n=5)$, cross-hatched bars] MPTP exposure on striatal PPT mRNA levels as measured by in situ hybridization histochemistry at three rostrocaudal levels [rostral $(A)$, mid $(B)$, and caudal $(C)$ ]. At all rostrocaudal levels similar decreases in PPT gene expression are evident in symptomatic groups compared with both controls $\left({ }^{*} p<0.01\right.$ vs normal controls; $\Delta p<0.05$ vs normal controls) and the asymptomatic group ( ${ }^{\wedge} p<$ 0.01 vs asymptomatic group; \#p $<0.05$ vs asymptomatic group). No significant decreases from control are seen in the asymptomatic group. $C D$, Caudate nucleus; $D L$, dorsolateral; $D M$, dorsomedial; $N A C C$, nucleus accumbens; $V L$, ventrolateral; $V M$, ventromedial.

brain, the AMPA subunit receptor GluR1 is also preferentially enriched in striosomes in the dorsal striatum, and GluR1 immunoreactivity aligns with regions high in substance $\mathrm{P}$ immunore- 
Normal

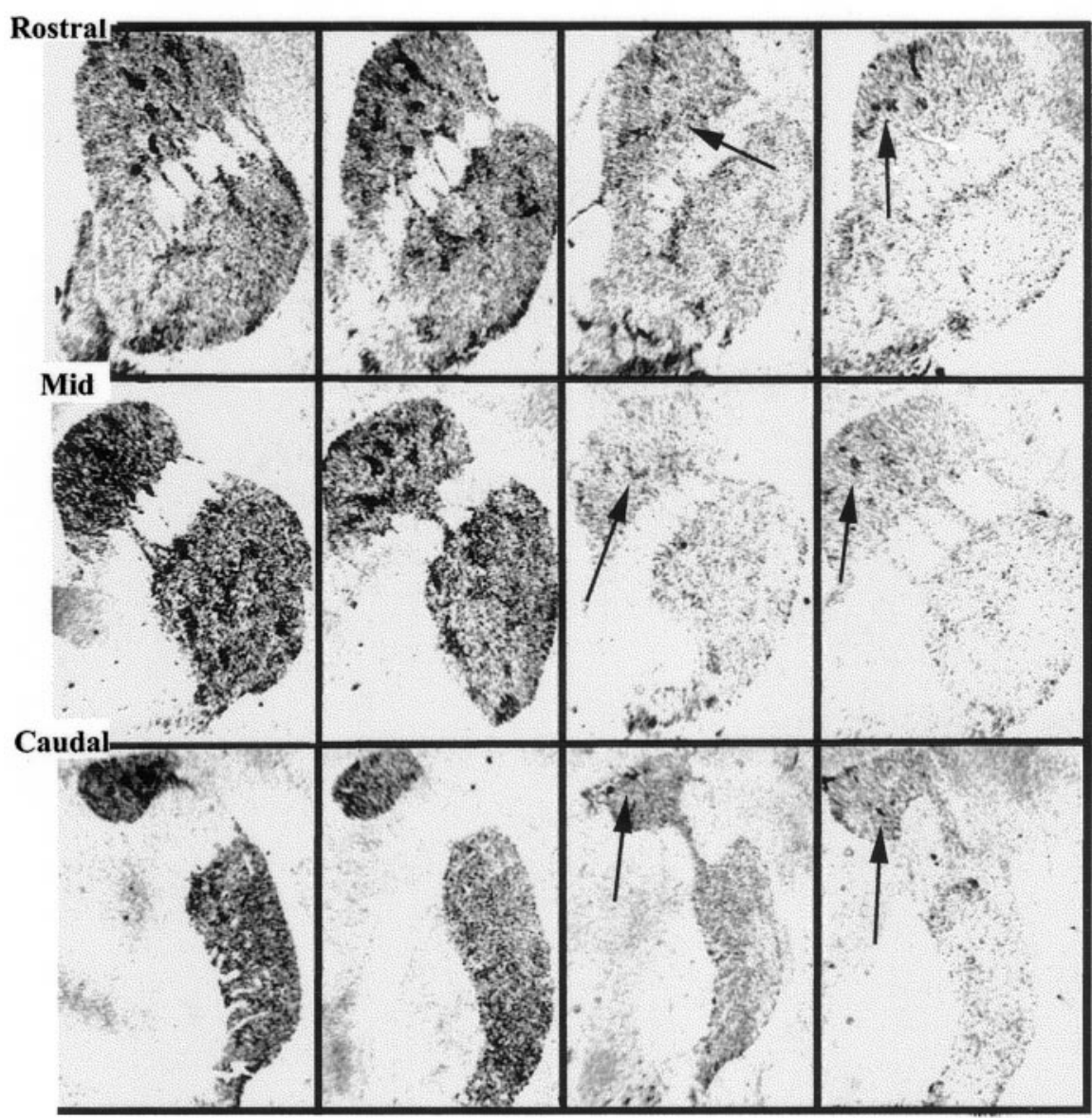

Acute Symp.

Figure 4. Autoradiograms of coronal brain sections showing PPT mRNA expression in control (Normal), asymptomatic (Asymp.), acutely symptomatic (Acute Symp.), and chronically symptomatic (Chronic Symp.) monkeys. The top row shows the rostral striatum, including the caudate nucleus, putamen, and nucleus accumbens. The middle row shows the mid level of the striatum, including the caudate nucleus, putamen, and external segment of the globus pallidus. The bottom row shows the caudal striatum, including the putamen, body of the caudate nucleus, and both the internal and external segments of the globus pallidus. Note the similarities between the asymptomatic animal and the control, and compare with the acutely and chronically symptomatic animals. Arrows in the caudate nucleus in acutely and chronically symptomatic animals indicate the partial sparing of PPT mRNA expression in the patch compartment, which is not seen in the putamen. activity (Martin et al., 1993). The functional significance of the preferential loss of PPT mRNA expression in the putamen and to a lesser extent in caudate patches in symptomatic animals and of the sparing of this pattern of gene expression in asymptomatic animals is unclear at this time. However, considering the different neurochemistry and the complex neurochemical regulation of input-output circuits of the patch or matrix compartments, these changes in PPT mRNA expression may be importantly involved in the dysregulation of striatal information processing and output circuitry in parkinsonian animals and may play an important role in the maintenance of striatal functioning in asymptomatic animals.

In MPTP-treated monkeys (Herrero et al., 1995; Jolkkonen et al., 1995), upregulated PPE gene expression from acute toxin exposure was unaltered by L-DOPA therapy but responsive to DA D2-selective agonists. In contrast, decreased PPT gene expression after acute MPTP exposure is normalized by L-DOPA treatment as well as by D1 or D2 agonist treatments (Morissette et al., 1999). These data, together with the current findings, suggest that striatal PPT gene expression, in contrast to striatal PPE gene expression (Schneider et al., 1999), may be more closely associated with motor status in MPTP-treated parkinsonian monkeys. This would suggest that the direct striatal output circuit may be more directly related to expression of parkinsonian symptoms than is the indirect circuit and may be a preferred therapeutic target.

In monkeys with parkinsonian motor deficits, PPT mRNA expression was significantly attenuated irrespective of the dura- tion of parkinsonism. The duration of parkinsonism appears to affect neuropeptide mRNA levels differently, because PPE mRNA was found previously to be upregulated in acutely, but not chronically, symptomatic parkinsonian monkeys (Schneider et al., 1999). In rats chronically administered methamphetamine, a progressive increase in PPT gene expression was observed that paralleled increased locomotor activity. After a $15 \mathrm{~d}$ withdrawal period, PPT mRNA levels were normalized as was locomotor activity (Zhang et al., 1997). In the same study, PPE gene expression was initially upregulated, returned to control values with repeated doses of methamphetamine, and decreased significantly below control values after a $15 \mathrm{~d}$ withdrawal period. These findings, together with our observations, support the concept that striatal PPT and PPE mRNA levels are differently regulated in response to changes in striatal DA levels and that only PPT mRNA expression reliably changes in response to chronic alterations in DAergic tone and reliably reflects the motor status of the animal.

The extent of the decreases in $\left[{ }^{3} \mathrm{H}\right]$ mazindol binding, particularly in sensorimotor striatal territories, in asymptomatic animals was somewhat surprising. In agreement with other studies (Pifl et al., 1991), we found significantly higher levels of striatal $\left[{ }^{3} \mathrm{H}\right]$ mazindol binding in the asymptomatic animals, particularly at mid and caudal striatal levels, than in symptomatic animals. It is possible that in the sensorimotor striatum in asymptomatic animals, there may be a compensatory downregulation of DA transporter sites labeled by $\left[{ }^{3} \mathrm{H}\right]$ mazindol such that the degree of DA denervation may be overestimated in these animals. In PD 
patients, measures of ligand binding to the DA transporter were less reliable markers of DA denervation and clinical condition than were direct measures of DA transporter protein or DA levels (Wilson et al., 1996). Because DA transporter mRNA expression is significantly decreased in advance of significant changes in tyrosine hydroxylase gene expression in normal aging (Bannon et al., 1992; Bannon and Whitty, 1997) and in some neurodegenerative conditions (Joyce et al., 1997), decreased $\left[{ }^{3} \mathrm{H}\right]$ mazindol binding in our asymptomatic animals may reflect an attempt by a partially damaged DA system to maximize the effects of DA released from residual terminals. Further work is necessary to clarify this issue. However, if it is assumed that the $\left[{ }^{3} \mathrm{H}\right]$ mazindol-binding results in the present study do reliably reflect DA denervation, then the lack of decreased PPT mRNA expression in the asymptomatic animals despite an 85-90\% loss of DA terminals in dorsal striatal areas may suggest that neurochemical systems other than the DA system may be involved in regulating striatal PPT expression. It has been suggested, for example, that serotonin neurotransmission may at least partially regulate striatal PPT gene expression. Administration of serotonin $2 \mathrm{~A} / 2 \mathrm{C}$ agonists effectively normalizes striatal PPT mRNA levels in rats with $>85 \%$ DA depletion (Gresch and Walker, 1999). Also, we (Schneider, 1990) and others (Pifl et al., 1991) have previously reported increased levels of 5-HT and 5-hydroxyindoleacetic acid levels in the striatum of asymptomatic MPTP-treated monkeys. Thus, increased striatal serotoninergic neurotransmission may contribute to the maintenance of normal PPT gene expression and motor function in asymptomatic animals with significant DAergic denervation. This possible compensatory process may not be available in symptomatic animals in which striatal 5-HT levels are significantly decreased (Perez-Otano et al., 1991; Pifl et al., 1991).

In the present study, the decrease in $\left[{ }^{3} \mathrm{H}\right]$ mazindol binding in acutely and chronically symptomatic monkeys was similar in the caudate nucleus and putamen. Humans with MPTP-induced parkinsonism after short-term exposure to high doses of MPTP have equal degrees of caudate and putamen DA loss, detected by $\left[{ }^{18} \mathrm{~F}\right]$ fluorodopa, compared with the differential and more extensive loss of the putamen DAergic function in idiopathic PD (Snow et al., 2000). Recent in vivo imaging data indicate that long-term intermittent injection of low doses of MPTP produces a more significant diminution of DAergic terminal density in the putamen than in the caudate, recapitulating a pattern of striatal DA loss in idiopathic PD (Wullner et al., 1994). Long-term low-dose MPTP treatment also produced exponential loss of striatal DA terminals over time, paralleling the appearance of overt parkinsonian signs (Wullner et al., 1994). Others have also reported a pattern of nigrostriatal fiber loss characteristic of that seen in PD in monkeys given single injections of MPTP (Moratalla et al., 1992). The differences between the present findings [i.e., similar caudate and putamen loss of DA terminals (assessed by $\left[{ }^{3} \mathrm{H}\right]$ mazindol binding)] and the above-mentioned primate studies are most likely to be attributable to the different MPTP regimens used.

In conclusion, this study demonstrates that changes in striatal PPT mRNA expression reflect the motor status of MPTPexposed monkeys and suggests an important influence of the direct striatal output system on expression of parkinsonian symptoms. In addition, striatal PPT mRNA levels may be regulated at least in part by non-DAergic systems, because PPT gene expression did not appear to be directly related to the extent of DAergic denervation, as reflected by $\left[{ }^{3} \mathrm{H}\right]$ mazindol binding, or to the duration of parkinsonian symptoms. A better understanding of striatal neuropeptide regulation under normal and DA denervation conditions should prove useful in developing new antiparkinsonian therapeutics.

\section{REFERENCES}

Aubert I, Ghrayeb I, Normand E, Bloch B (2000) Phenotypical characterization of the neurons expressing the D1 and D2 dopamine receptors in the monkey striatum. J Comp Neurol 418:22-32.

Bannon MJ, Whitty CJ (1997) Age-related and regional differences in dopamine transporter mRNA expression in human midbrain. Neurology 48:969-977.

Bannon MJ, Poosch MS, Goebel DJ, Cassin B, Kapatos G (1992) Dopamine transporter mRNA content in human substantia nigra decreases precipitously with age. Proc Natl Acad Sci USA 89:7095-7099.

Beach TG, McGeer EG (1984) The distribution of substance P in the primate basal ganglia: an immunohistochemical study of baboon and human brain. Neuroscience 13:29-52.

Delong HR (1990) Primate models of movement disorders of basal ganglia origin. Trends Neurosci 13:281-285.

Gerfen CR (1984) The neostriatal mosaic: compartmentalization of corticostriatal input and striatonigral output systems. Nature 311:461-464.

Gerfen CR (1992) The neostrial mosaic: multiple levels of compartmental organization in the basal ganglia. Annu Rev Neurosci 15:285-320.

Gerfen CR, Engber TM, Mahan LC, Susel A, Chase TN, Monsma FJ, Sibley DR (1990) D1 and D2 dopamine receptor-regulated gene expression of striatonigral and striatopallidal neurons. Science 250:1429-1432.

Gresch PJ, Walker PD (1999) Serotonin-2 receptor stimulation normalizes striatal preprotachykinin messenger RNA in an animal model of Parkinson's disease. Neuroscience 93:831-841.

Harmar AJ, Armstrong A, Pascall JC, Chapman K, Rosie R, Curtis A, Going J, Edwards CRW, Fink G (1986) cDNA sequence of human beta-preprotachykinin, the common precursor to substance $\mathrm{P}$ and neurokinin-A. FEBS Lett 208:67-72.

Herrero MT, Augood SJ, Hirsch EC, Javoy-Agid F, Luquin MR, Agid Y, Obeso JA, Emson PC (1995) Effects of L-DOPA on preproenkephalin and preprotachykinin gene expression in the MPTP-treated monkey striatum. Neuroscience 68:1189-1198

Jolkkonen J, Jenner P, Marsden CD (1995) L-DOPA administration differentially regulates enkephalin substance $\mathrm{P}$ gene expression in the caudate-putamen of MPTP-treated common marmoset. Mol Brain Res 32:297-307.

Joyce JN, Smutzer G, Whitty CJ, Myers A, Bannon MJ (1997) Differential modification of dopamine transporter and tyrosine hydroxylase mRNAs in midbrain of subjects with Parkinson's, Alzheimer's with parkinsonism, and Alzheimer's disease. Mov Disord 12:885-897.

Langer LF, Graybiel AM (1989) Distinct nigrostriatal projection systems innervate striosomes and matrix in the primate striatum. Brain Res 498:344-350.

Martin LJ, Blackstone CD, Huganir RL, Price DL (1993) The striatal mosaic in primates: striosomes and matrix are differentially enriched in ionotropic glutamate receptor subunits. J Neurosci 13:782-792.

Moratalla R, Quinn B, DeLanney LE, Irwin I, Langston JW, Graybiel AM (1992) Differential vulnerability of primate caudate-putamen and striosomes-matrix dopamine systems to the neurotoxic effects of 1-methyl-4-phenyl-1,2,3,6-tetrahydropyridine. Proc Natl Acad Sci USA 89:3859-3863.

Morissette M, Grondin R, Goulet M, Bedard PJ, Di Paolo T (1999) Differential regulation of striatal preproenkephalin and preprotachykinin mRNA levels in MPTP-lesioned monkeys chronically treated with dopamine D-1 or D-2 receptor agonists. J Neurochem 72:682-692.

Parent A, Hazrati LN (1995) Functional anatomy of the basal ganglia. I. The cortico-basal ganglia-thalamo-cortical loop. Brain Res Rev 20:91-127.

Perez-Otano I, Herrero MT, Oset C, De Caballos ML, Luquin MR, Obeso JA, Del Rio J (1991) Extensive loss of brain dopamine and serotonin induced by chronic administration of MPTP in the marmoset. Brain Res 567:127-132.

Pifl C, Schingnitz G, Hornykiewicz O (1991) Effects of 1-methyl-4phenyl-1,2,3,6-tetrahydropyridine on the regional distribution of brain monoamines in the rhesus monkey. Neuroscience 44:591-605.

Pope-Coleman A, Tinker JP, Schneider JS (2000) Effects of GM1 ganglioside treatment on pre- and postsynaptic dopaminergic markers in the striatum of parkinsonian monkeys. Synapse 36:120-128.

Rioux L, Frohna PA, Joyce JN, Schneider JS (1997) The effects of chronic levodopa treatment on pre- and postsynaptic markers of dopaminergic function in striatum of parkinsonian monkeys. Mov Disord 12:148-158.

Schneider JS (1990) Chronic exposure to low doses of MPTP. II. Neurochemical and pathological consequences in cognitively-impaired, motor asymptomatic monkeys. Brain Res 534:25-36.

Schneider JS, Pope-Coleman A, Van Velson M, Menzaghi F, Lloyd GK 
(1998) Effects of SIB-1508Y, a novel neuronal nicotinic acetylcholinergic receptor agonist, on motor behavior in parkinsonian monkeys. Mov Disord 13:637-642.

Schneider JS, Decamp E, Wade T (1999) Striatal preproenkephalin gene expression is upregulated in acute but not chronic parkinsonian monkeys: implications for the contribution of the indirect striatopallidal circuit to parkinsonian symptomatology. J Neurosci 19:6643-6649.

Snow BJ, Vingerhoets FJ, Langston JW, Tetrud JW, Sossi V, Caline DB (2000) Pattern of dopaminergic loss in the striatum of humans with MPTP induced parkinsonism. J Neurol Neurosurg Psychiatry 68:313-316.

Wilson JM, Levey AI, Rajput A, Ang L, Guttman M, Shannak K, Niznik HB, Hornykiewicz O, Pifl C, Kish SJ (1996) Differential changes in neurochemical markers of striatal dopamine nerve terminals in idiopathic Parkinson's disease. Neurology 47:718-726.
Wullner U, Pakzaban P, Brownell AL, Hantraye P, Burns L, Shoup T, Elmaleh D, Petto AJ, Spealman RD, Brownell GL (1994) Dopamine terminal loss and onset of motor symptoms in MPTP-treated monkeys: a positron emission tomography study with 11C-CFT. Exp Neurol 126:305-309.

Zeng BY, Jolkkonen J, Jenner P, Marsden CD (1995) Chronic L-DOPA treatment differentially regulates gene expression of glutamate decarboxylase, preproenkephalin and preprotachykinin in the striatum of 6-hydroxydopamine-lesioned rat. Neuroscience 66:19-28.

Zhang Y, Landas K, Mueller H, Angulo JA (1997) Progressive augmentation of striatal and accumbal preprotachykinin mRNA levels by chronic treatment with methamphetamine and effect of concurrent administration of $N$-methyl-D-aspartate receptor antagonist MK-801. Neuropharmacology 36:325-334. 